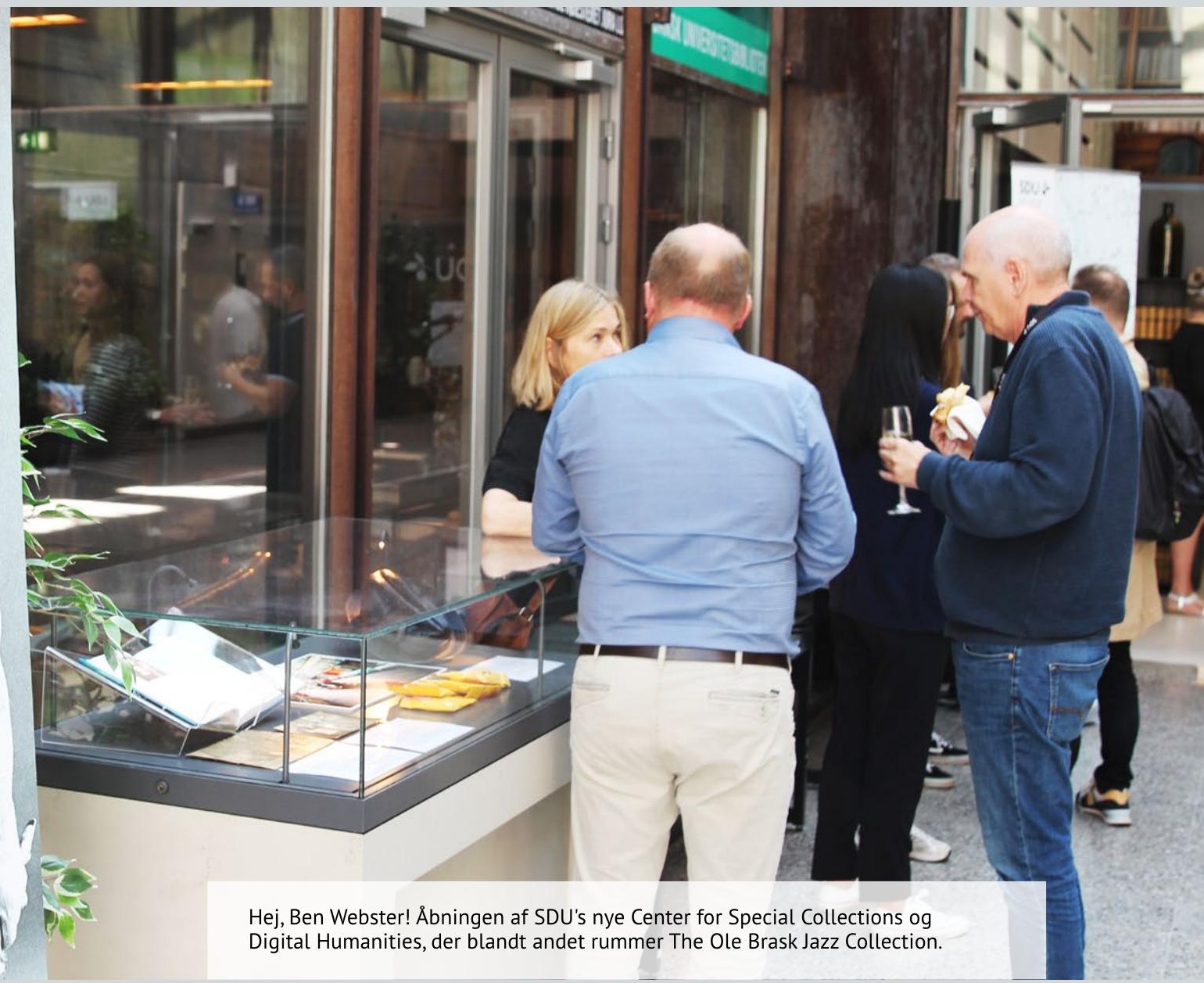

\title{
Humaniora tilsat strøm
}

Digital Humanities er et buzzword med stayingpower. Et nyt center på SDU forener Digital Humanities med bibliotekets mangeårige arbejde med særsamlinger.

Åbningen af det nye Center for Special Collections og Digital Humanities (SCDH) blev i starten af september fejret i centerets tilknyttede forskerlæsesal, som samtidig er nyindrettet.

Centeret samler bibliotekets arbejde med at bevare, digitalisere og formidle de mange særsamlinger, som biblioteket råder over og er et samlende punkt for arbejdet med Digital Humanities på SDU. I spidsen for centeret står Kamilla Jensen Husen, ph.d., og leder af Center for Special Collections og Digital Humanities, og hun understreger det vigtige $\mathrm{i}$ at holde centeråbningen fysisk.

- En sådan åbning er en netværksbegivenhed. Biblioteket er en naturlig medspiller for forskningsmiljøerne. Vi skal være der, hvor vores forskere er, og hvis de vil have Digital Humanities, så sørger vi for det. Vi er med til at binde alt det sammen, der foregår omkring Digital Humanities og Special Collections på SDU - vi er knuden i midten af netværket. Centeret kan understøtte både forskere og studerende i forhold til undervisning og forskning samtidig med, at vi får sat vores egne samlinger i spil, siger Kamilla Jensen Husen.

Medarbejderne på centeret har et stort netværk, som kan bruges til at sammenkæde forskellige forskere og faglige interesser.

"Vi ved, hvor der sidder nogen, der kan hjælpe. Fx kontakter H. C. Andersen Centeret os og spørger til vores udstyr. Og så sætter vi dem i forbindelse med folk fra Tek, og nu skal de scanne
Af Lotte Thing Rasmussen, journalist, specialkonsulent, Syddansk Universitetsbibliotek Fotos: Jeppe Lomholt Akselsbo 


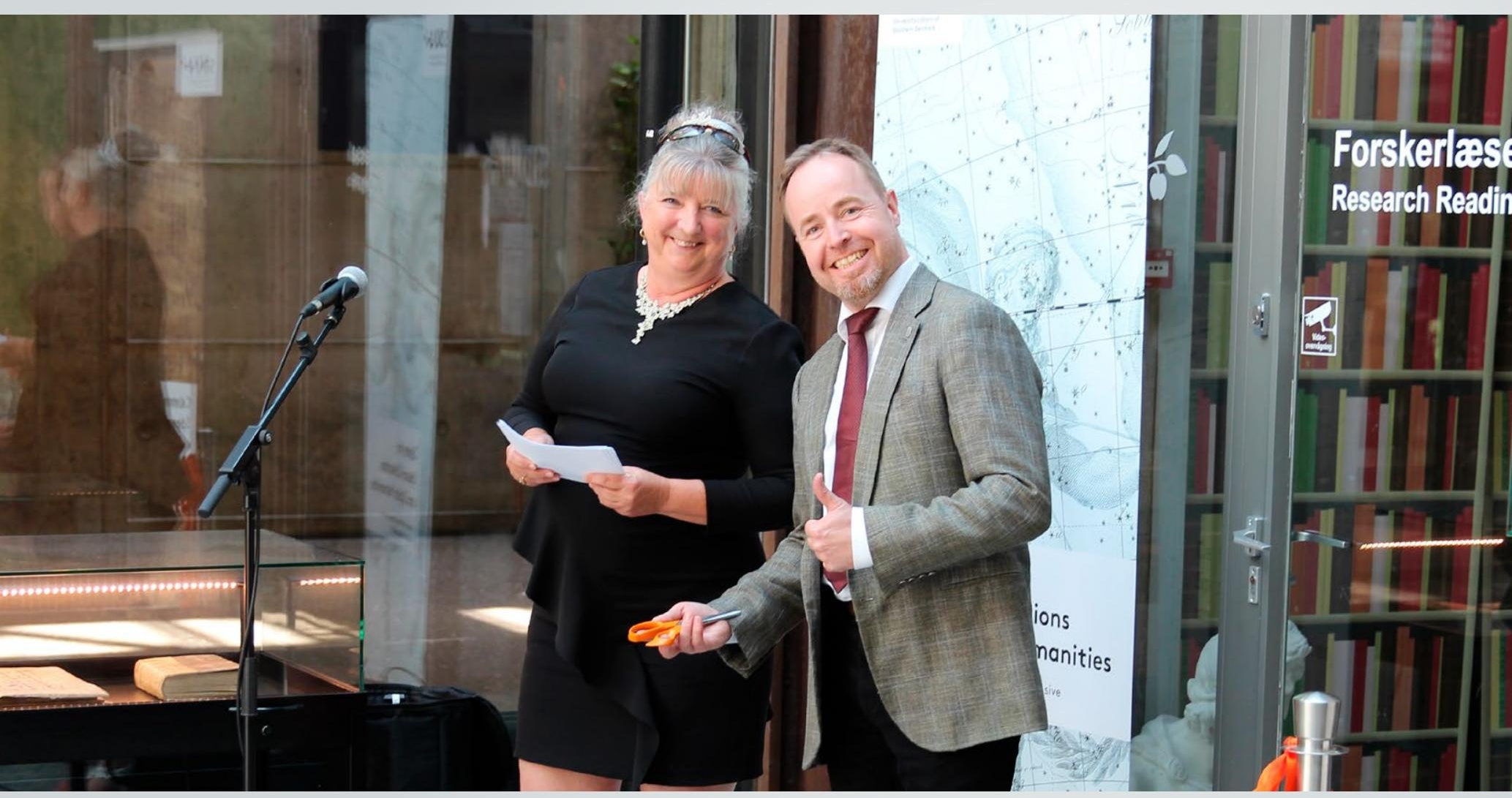

Med taler, kage og jazzmusik var den nyindrettede Forskerlæsesal rammen om åbningen af det nye Center for Special Collections og Digital Humanities. På Forskerlæsesalen er det muligt at få adgang til materiale fra særsamlingerne, de såkaldte Special Collections.

nødvendigvis en em af klassisk historie og viden. Derfor kræver det et ekstra touch at indrette. Det var Charlotte Wien, Forskningschef, Professor, Forsknings- og Analysesektionen, inde på i sin åbningstale med disse ord:

- Dels skal læsesalen være et rum til indgående studier af bibliotekets og andres skatte, dels et levende laboratorium for digitalisering og restaurering af vores kostbareste værker. Salen er, i dens kitchede fake Harry Potter med en snert af Chesterfield-stil, en slags ironisk kommentar til både "Rustenborg" (= SDU, red.) og vores topmoderne bibliotek, sagde Charlotte Wien.

Kamilla supplerer:

- Jeg synes, vi har ramt den helt rigtige atmosfære af, at her er viden til.

Efter en kort tænkepause:

- Og her kan ny viden skabes. Digital Humanities er også et kulturarvsredskab, det kan vise nye veje til kulturformidling og tilgængeliggøre materialer, der er så skrøbelige, at vi ikke kan bevare dem mere. Ting forgår.
Men det behøver de ikke. De kan gøres tilgængelige for hele verden, siger Kamilla Jensen Husen.

Og så er det tilmed et ægte verdensmål, nemlig det 11. af slagsen (Bæredygtige byer og lokalsamfund), hvor delmål 4 lyder: Bevaring og formidling af verdens kulturarv.
Ting forgår. Men det behøver de ikke. De kan gøres tilgængelige for hele verden.

Kamilla Jensen Husen

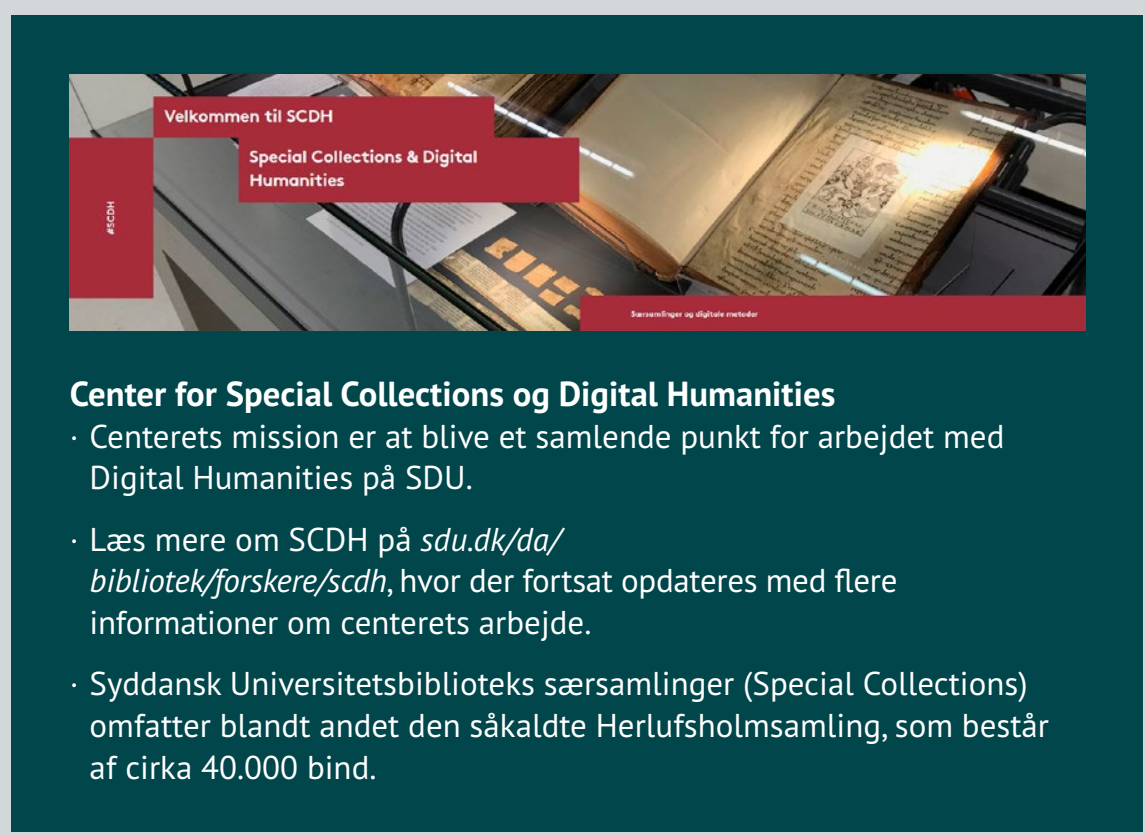

